\title{
Inferring absorbing organic carbon content from AERONET data
}

\author{
A. Arola ${ }^{1}$, G. Schuster ${ }^{2}$, G. Myhre ${ }^{3}$, S. Kazadzis ${ }^{4}$, S. Dey ${ }^{5}$, and S. N. Tripathi ${ }^{6,7}$ \\ ${ }^{1}$ Finnish Meteorological Institute, P. O. Box 1627, 70211 Kuopio, Finland \\ ${ }^{2}$ NASA Langley Research Center Hampton, VA 23681, USA \\ ${ }^{3}$ Center for International Climate and Environmental Research-Oslo (CICERO), Blindern, 0318 Oslo, Norway \\ ${ }^{4}$ Institute for Environmental Research \& Sustainable Development, National Observatory of Athens, 15236 Athens, Greece \\ ${ }^{5}$ Department of Atmospheric Sciences, University of Illinois at Urbana Champaign, Urbana, IL, USA \\ ${ }^{6}$ NASA Goddard Space Flight Center, Greenbelt, MD 20770, USA \\ ${ }^{7}$ Department of Civil Engineering, Indian Institute of Technology, Kanpur-208016, India
}

Received: 1 July 2010 - Published in Atmos. Chem. Phys. Discuss.: 2 August 2010

Revised: 26 November 2010 - Accepted: 24 December 2010 - Published: 11 January 2011

\begin{abstract}
Black carbon, light-absorbing organic carbon (often called "brown carbon") and mineral dust are the major light-absorbing aerosols. Currently the sources and formation of brown carbon aerosol in particular are not well understood. In this study we estimated the amount of light-absorbing organic carbon and black carbon from AERONET measurements. We find that the columnar absorbing organic carbon (brown carbon) levels in biomass burning regions of South America and Africa are relatively high (about $15-20 \mathrm{mg} \mathrm{m}^{-2}$ during biomass burning season), while the concentrations are significantly lower in urban areas in US and Europe. However, we estimated significant absorbing organic carbon amounts from the data of megacities of newly industrialized countries, particularly in India and China, showing also clear seasonality with peak values up to $30-35 \mathrm{mg} \mathrm{m}^{-2}$ during the coldest season, likely caused by the coal and biofuel burning used for heating. We also compared our retrievals with the modeled organic carbon by the global Oslo CTM for several sites. Model values are higher in biomass burning regions than AERONET-based retrievals, while the opposite is true in urban areas in India and China.
\end{abstract}

\section{Introduction}

Aerosols affect both directly and indirectly the Earth's climate. Currently, aerosol forcing is the largest uncertainty in assessing the anthropogenic climate change (IPCC, 2007). Recent research (e.g., Myhre, 2009) has emphasized that

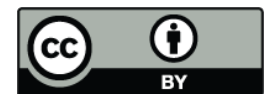

Correspondence to: A. Arola (antti.arola@fmi.fi) in addition to aerosol optical depth (AOD), assessments of aerosol effects on climate require globally distributed information on aerosol characteristics such as size, composition and optical properties, particularly absorption. Moreover, it is of importance to get better understanding of the different absorbing components.

Black carbon (BC) is the main absorbing component present in atmospheric aerosols. In addition, soil dust absorbs light in the UV and visible, and some organic materials absorb in the UV. The enhanced UV absorption feature was observed for instance by Martins et al. (2009), who analyzed data from Sao Paulo. Kirchstetter et al. (2004) showed strong spectral dependence of the light absorption by organic aerosols in the UV. Similar absorption characteristics, attributed to organics, have been found in several other reported measurements (e.g. Yang et al., 2009; Alexander et al., 2008; Lewis et al., 2008; Russell et al., 2010, and references therein). The sources and formation of lightabsorbing organic carbon compounds (often called as "brown carbon") and their temporal variability, however, are currently not well understood (Andreae and Gelencsér, 2006; Bergstrom et al., 2007). Moreover, their optical properties change during aging (Laskin et al., 2010).

Recently, Schuster et al. $(2005,2009)$ have introduced a methodology to derive information about both aerosol black carbon content and water uptake from AErosol RObotic NETwork (AERONET)-retrieved complex refractive index. Koven and Fung (2006) separated the absorption by black carbon from absorption by dust, applying the wavelengthdependent absorption in AERONET data. Koch et al. (2009) compared modeled BC concentrations against available measurements (including an updated version of the Schuster et al. (2005) data set) and found underestimation of BC

Published by Copernicus Publications on behalf of the European Geosciences Union. 
by global aerosol models and relatively large diversity between different models. Model behavior (including the emissions) against OC estimates has not been compared to measurements due to the lack of a global reliable OC surface or columnar data set. Sato et al. (2003) focused on OC in addition to $\mathrm{BC}$, but they still constrained the modeling by aerosol absorption optical depth from AERONET, not attempting to retrieve directly OC concentrations from AERONET data. Russell et al. (2010) assessed the usefulness of AERONET-retrieved single scattering albedo (SSA), aerosol absorption optical depth (AAOD), and absorption Angstrom exponent (AAE) as indicators of aerosol composition, including black carbon, organic matter, and mineral dust. They did not, however, estimate the composition from AERONET measurements.

In our study reported herein, the approach of Schuster et al. (2005) was extended and refined to assess whether relevant information about the relative role of organic carbon (OC) absorption can be inferred from AERONET measurements. We retrieved the columnar mass concentration of absorbing organic carbon in $\mathrm{mg} \mathrm{m}^{-2}$ and $\mathrm{OC} / \mathrm{BC}$ ratio from all available AERONET Level-2 data. We find that the levels in biomass burning regions of South America and Africa are relatively high, while the concentrations are significantly lower in urban areas in US and Europe. However, significant absorbing OC amounts were estimated from the data of megacities of newly industrialized countries, particularly in India and China during coldest season.

\section{Data and methods}

\subsection{AERONET data}

AERONET (AErosol RObotic NETwork) is a globally distributed network of automatic sun and sky scanning radiometers that measure at several wavelengths, typically centered at $0.34,0.38,0.44,0.50,0.67,0.87,0.94$, and $1.02 \mu \mathrm{m}$. Each band has a full width of approximately $0.010 \mu \mathrm{m}$ at half maximum (FWHM). All of these spectral bands are utilized in the direct Sun measurements, while four of them are used for the sky radiance, $0.44,0.67,0.87$ and $1.02 \mu \mathrm{m}$. Spectral aerosol optical depth (AOD) is obtained from direct sun measurements, and inversion products of other aerosol optical properties, such as single scattering albedo (SSA), refractive indices and the column integrated aerosol size distributions above the measurement site are provided at the sky radiance wavelengths (Holben et al., 1998).

In our study, we used level 2.0 data (quality assured) of refractive indices at four retrieval wavelengths $0.44,0.67$, 0.87 and $1.02 \mu \mathrm{m}$ to match model derived refractive indices, in order to retrieve black carbon and organic carbon concentrations.

\subsection{Retrieval of absorbing $\mathrm{OC}$}

Schuster et al. (2005) demonstrated an approach to retrieve black carbon concentration and specific absorption from AERONET retrievals of imaginary refractive indices. Dey et al. (2006) applied this same approach, but included additionally $\mathrm{OC}$ or dust as absorbing component. However, they did not focus on retrieved OC concentrations, which is the main focus of our study. We utilized the AERONET measurements of refractive index, and refined the approach of Schuster et al. (2005) to focus on spectral absorption and possible influence of $\mathrm{OC}$, to assess whether this kind of information can be retrieved to have climatologically relevant information. Since the main details of the methodology are comprehensively described elsewhere, particularly in Schuster et al. (2005), only main points and assumptions used in our study are summarized here.

We applied the Maxwell-Garnett (MG) mixing rule for a mixture of $\mathrm{BC}, \mathrm{OC}$ and $\left(\mathrm{NH}_{4}\right)_{2}\left(\mathrm{SO}_{4}\right)$ embedded in water host. The assumed refractive index values of these components are given in the Table 1 . We used the values for $\mathrm{BC}$ refractive index and density suggested by Bond and Bergstrom (2006). We considered a spectrally independent imaginary part, $(k(\lambda))$ except for OC, for which we fixed $k(\lambda)$ at $440 \mathrm{~nm}$ and $670 \mathrm{~nm}$ with the values used by Kirchstetter et al. (2004). There are a lot of different OC species with varying absorption properties. However, many of the organic species do not absorb significantly and it has to be stressed that in our approach "organic carbon" should be taken as equivalent for concentration of components causing enhanced absorption at the shortest wavelengths that cannot be explained by BC.

From MG, $k(\lambda)$ were computed for different combinations of volume fractions of $\mathrm{BC}\left(f_{\mathrm{BC}}\right)$ and $\mathrm{OC}\left(f_{\mathrm{OC}}\right)$ by minimizing the following equation:

$\chi^{2}=\sum_{i=1}^{4} \frac{\left(k_{i}^{\mathrm{rtv}}-k_{i}^{\mathrm{cal}}\right)^{2}}{\left(k_{i}^{\mathrm{rtv}}\right)^{2}}$,

where $k_{i}^{\mathrm{rtv}}$ is the AERONET-retrieved imaginary index and $k_{i}^{\mathrm{cal}}$ is the value based on MG mixing rule, $i$ is the summation index over four wavelengths from AERONET.

The absorbing OC concentration is calculated then

$[\mathrm{OC}]=f_{\mathrm{OC}} \cdot \rho_{\mathrm{OC}} \cdot \int \frac{d V}{d \ln r} d \ln r$,

where $f_{\mathrm{OC}}$ is volume fraction of absorbing $\mathrm{OC}$ that gave the best fit in the Eq. (1), $\frac{d V}{d \ln r}$ is the particle volume distribution (in $\mu \mathrm{m}^{3} \mu \mathrm{m}^{-2}$ ), available from the AERONET inversion product. For a density of $\mathrm{OC}\left(\rho_{\mathrm{OC}}\right)$, we used the same value of $1.2 \mathrm{~g} \mathrm{~cm}^{-3}$ that was suggested by Turpin and Lim (2001).

In order to exclude dust dominated cases, we processed only those retrievals that had a ratio of fine mode to total volume concentration larger than 0.5. Moreover, we included the spectral imaginary index with the following restriction, AERONET-based imaginary index at $440 \mathrm{~nm}$ had 
Table 1. Refractive index values of the components, real part $(n)$ and imaginary part $(k)$. All the components are assumed to be spectrally constant, except for OC whose imaginary index at $440 \mathrm{~nm}$ and $670 \mathrm{~nm}$ is by Kirchstetter et al. (2004) and zero at $870 \mathrm{~nm}$ and $1020 \mathrm{~nm}$. Shown are also the imaginary index values for OC, based on Chen and Bond (2010) and Sun et al. (2007), that were used to assess the sensitivity of the OC retrieval for the assumed imaginary index.

\begin{tabular}{lrr}
\hline & $n$ & $k$ \\
\hline Water & 1.33 & $1.96 \times 10^{-9}$ \\
$\left(\mathrm{NH}_{4}\right)_{2}\left(\mathrm{SO}_{4}\right)$ & 1.53 & $10^{-7}$ \\
Soot & 1.95 & 0.79 \\
OC, Kirchstetter et al. (2004) & 1.53 & $0.073 / 0.0034(440 \mathrm{~nm} / 670 \mathrm{~nm})$ \\
OC, Chen and Bond (2010), $210^{\circ} \mathrm{C}$ & 1.53 & $0.0122 / 0.0013(440 \mathrm{~nm} / 670 \mathrm{~nm})$ \\
OC, Chen and Bond (2010), $360^{\circ} \mathrm{C}$ & 1.53 & $0.0525 / 0.0050(440 \mathrm{~nm} / 670 \mathrm{~nm})$ \\
OC, Sun et al. (2007), WSOC & 1.53 & $0.0232 / 0.0032(440 \mathrm{~nm} / 670 \mathrm{~nm})$ \\
OC, Sun et al. (2007), WISOC & 1.53 & $0.1908 / 0.0131(440 \mathrm{~nm} / 670 \mathrm{~nm})$ \\
\hline
\end{tabular}
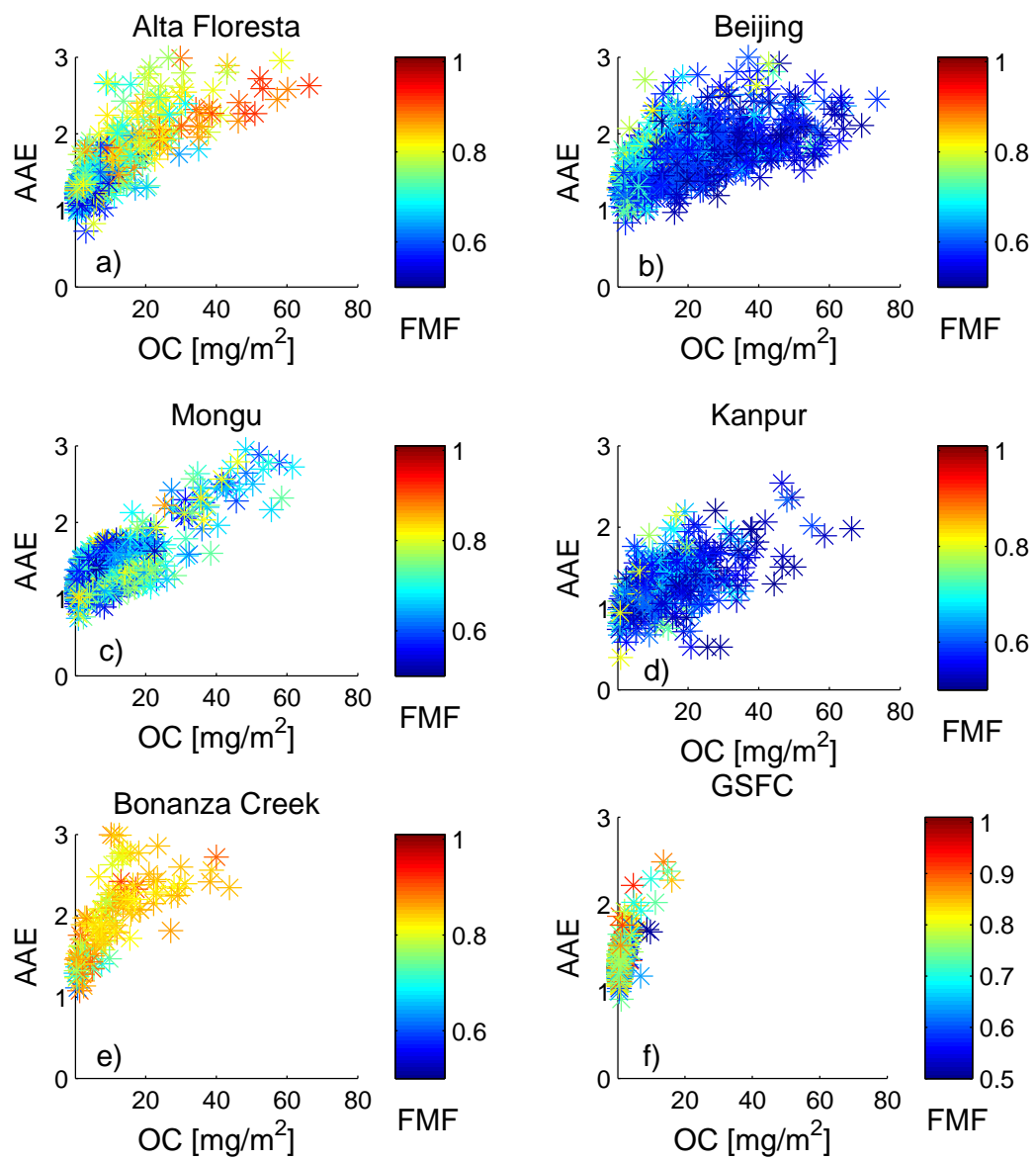

Fig. 1. Absorbing OC column concentrations $\left[\mathrm{mg} \mathrm{m}^{-2}\right.$ ] as a function of AAE from 440/670 nm wavelength pair and the ratio of fine mode to total volume concentration, fine mode fraction (FMF) shown as color. Name of the site is indicated at the top of each subplot.

to be larger than the mean of the imaginary indices at 670 , 870 and $1020 \mathrm{~nm}$.

Figure 1 shows an example of our absorbing OC retrievals for several sites as a function of AAE and fine mode to total volume concentration, fine mode fraction (FMF). AAE is calculated from $440 \mathrm{~nm}$ and $670 \mathrm{~nm}$ wavelength pair. It can be noted that the mean FMF in Kanpur and Beijing is smaller compared to the other sites. On average, an increase in AAE relates to stronger increase in the retrieved absorbing OC amount in Kanpur and Beijing than in biomass burning dominated sites. This is caused by both $f_{\mathrm{OC}}$ and total volume concentration (in Eq. 2) being larger for any given AAE in 


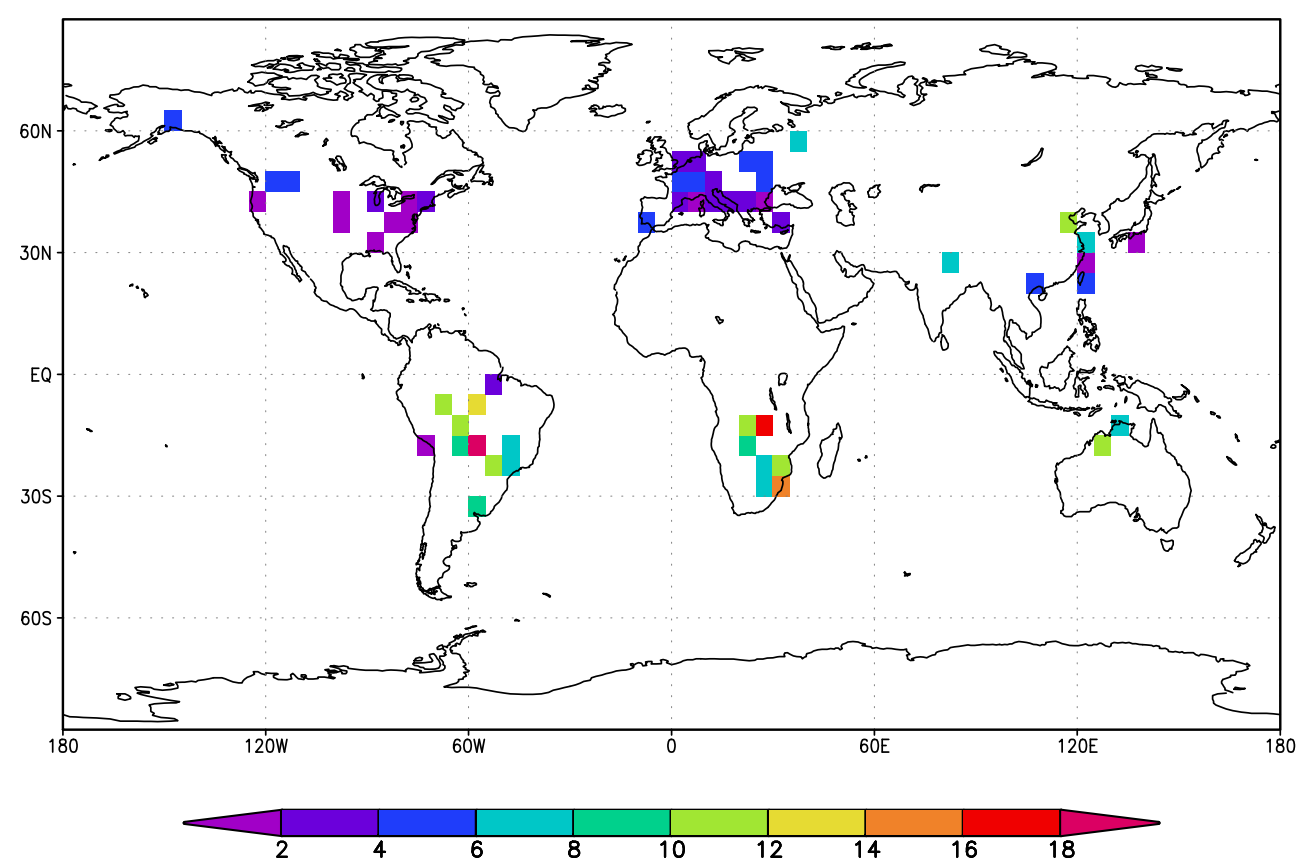

Fig. 2. Mean absorbing OC concentration $\left(\mathrm{mg} \mathrm{m}^{-2}\right)$ inferred from AERONET-retrieved imaginary indices for September.

these sites. Russell et al. (2010) and Shinozuka et al. (2009) showed similar relationships between AAE and total organic mass fraction for data over Central Mexico. However, in our case the relationship should be more evident, since we do not include total but absorbing OC.

\section{Results}

We included all the AERONET sites and calculated the monthly means of different retrieved parameters at $5 \times 5^{\circ}$ boxes. This means that in some regions several sites are included within one $5 \times 5^{\circ}$ degree box, particularly in Europe and US. In addition, it was required that each month includes at least 10 measurements. We also stress that since we used Level-2 data, our retrievals are essentially restricted to the cloud-free cases with AOD at $440 \mathrm{~nm}$ larger than 0.4 and solar zenith angle larger than $50^{\circ}$. This will bias the concentrations towards high values in many locations and months.

Schuster et al. (2005) did not include OC as a possible absorbing component, and estimated that this causes a positive bias of less than $9 \%$ in their retrieval of black carbon, when organic carbon aerosols are present. Therefore, by including organic carbon in this retrieval not only allows estimates for absorbing OC, but it leads to more accurate BC concentrations. Koch et al. (2009) compared modeled BC concentrations against available measurements (including an updated version of Schuster et al. (2005) data set) and found underestimation of $\mathrm{BC}$ by global models and relatively large diversity between different global aerosol models. Part of this can be attributed to a systematic bias caused by neglect- ing wavelength dependence in AERONET- retrieved absorption. However, this is not a major explanation, since the difference between modeled and measurement-based BC was much larger in many cases.

Figure 2 shows the retrieved monthly mean absorbing organic carbon column concentration (in $\mathrm{mg} \mathrm{m}^{-2}$ ) in September. During this month, that includes most data and sites, the values of absorbing OC concentration are very similar in US and Europe (around 2-6 $\mathrm{mg} \mathrm{m}^{-2}$ ), while in the biomass burning regions of South America and South Africa they are typically higher and around $10-15 \mathrm{mg} \mathrm{m}^{-2}$. There are also elevated concentrations retrieved in the Top End of the Northern Territory of Australia in September that is within the burning season (e.g Luhar et al., 2008). Qin and Mitchell (2009) classified a large part of the AERONET data as smoke in this region during the burning season, but also with class they called "super-absorptive". This class was distinct with very low single scattering albedo $(0.7$ at $500 \mathrm{~nm})$ and enhanced absorption at $440 \mathrm{~nm}$. They argued that the most likely source for these "super-absorptive" particles is the burning of Australian hummock grasses (Spinifex), with high levels of both black and organic carbon.

The data from Bonanza Creek in Alaska and also from Moscow and Zvenigorod shows relatively high values, particularly if compared to the $\mathrm{BC}$ levels (OC/BC will be shown in the Fig. 4). The grid-box including Beijing and XiangHe (about $55 \mathrm{~km}$ apart from each other) shows increased concentrations in China, however this region exhibits the highest values during winter months as shown and discussed later. 
Table 2. Sites that were focused on in this study. For each month, information on the data volume is given; $N=$ total number of retrievals, $\mathrm{D}=$ number of days having retrievals, $\mathrm{Y}=$ number of years having retrievals.

\begin{tabular}{|c|c|c|c|c|c|c|}
\hline Month & 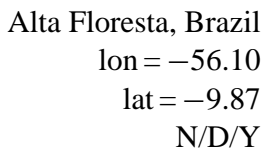 & $\begin{array}{r}\text { Beijing, China } \\
\text { lon }=116.38 \\
\text { lat }=39.98 \\
\text { N/D/Y }\end{array}$ & $\begin{array}{r}\text { Bonanza Creek, Canada } \\
\text { lon }=-148.32 \\
\text { lat }=64.74 \\
\mathrm{~N} / \mathrm{D} / \mathrm{Y}\end{array}$ & $\begin{array}{r}\text { GSFC, USA } \\
\text { lon }=-76.84 \\
\text { lat }=38.99 \\
\mathrm{~N} / \mathrm{D} / \mathrm{Y}\end{array}$ & $\begin{array}{r}\text { Kanpur, India } \\
\text { lon }=80.23 \\
\text { lat }=26.51 \\
\text { N/D/Y }\end{array}$ & $\begin{array}{r}\text { Mongu, Zambia } \\
\text { lon }=23.15 \\
\text { lat }=-15.25 \\
\mathrm{~N} / \mathrm{D} / \mathrm{Y}\end{array}$ \\
\hline 1 & $0 / 0 / 0$ & $89 / 31 / 6$ & $0 / 0 / 0$ & $0 / 0 / 0$ & $107 / 48 / 6$ & $2 / 1 / 1$ \\
\hline 2 & 0/0/0 & $74 / 26 / 6$ & $0 / 0 / 0$ & $0 / 0 / 0$ & $26 / 15 / 6$ & $0 / 0 / 0$ \\
\hline 3 & $0 / 0 / 0$ & $31 / 19 / 6$ & $0 / 0 / 0$ & $5 / 4 / 3$ & $6 / 3 / 1$ & $2 / 1 / 1$ \\
\hline 4 & $0 / 0 / 0$ & $15 / 11 / 4$ & $0 / 0 / 0$ & $6 / 4 / 3$ & $0 / 0 / 0$ & $0 / 0 / 0$ \\
\hline 5 & $0 / 0 / 0$ & $43 / 29 / 6$ & $3 / 2 / 1$ & $50 / 28 / 9$ & $5 / 3 / 1$ & $13 / 5 / 3$ \\
\hline 6 & $0 / 0 / 0$ & $52 / 33 / 7$ & $14 / 8 / 3$ & $79 / 44 / 12$ & $1 / 1 / 1$ & $45 / 19 / 5$ \\
\hline 7 & $4 / 3 / 1$ & $54 / 34 / 8$ & $13 / 10 / 5$ & $72 / 52 / 12$ & $1 / 1 / 1$ & $77 / 42 / 10$ \\
\hline 8 & $189 / 86 / 11$ & $47 / 34 / 7$ & $92 / 28 / 4$ & $80 / 52 / 11$ & $0 / 0 / 0$ & $246 / 103 / 10$ \\
\hline 9 & $140 / 73 / 11$ & $58 / 29 / 6$ & $10 / 3 / 1$ & $53 / 29 / 13$ & $12 / 7 / 3$ & $368 / 131 / 10$ \\
\hline 10 & $78 / 44 / 10$ & $72 / 33 / 7$ & 0/0/0 & $13 / 9 / 5$ & $21 / 12 / 5$ & $197 / 90 / 11$ \\
\hline 11 & $5 / 5 / 3$ & $64 / 26 / 7$ & $0 / 0 / 0$ & $7 / 3 / 2$ & 77/38/7 & $12 / 10 / 3$ \\
\hline 12 & $5 / 2 / 1$ & $61 / 27 / 6$ & $0 / 0 / 0$ & $0 / 0 / 0$ & $101 / 50 / 6$ & 0/0/0 \\
\hline
\end{tabular}
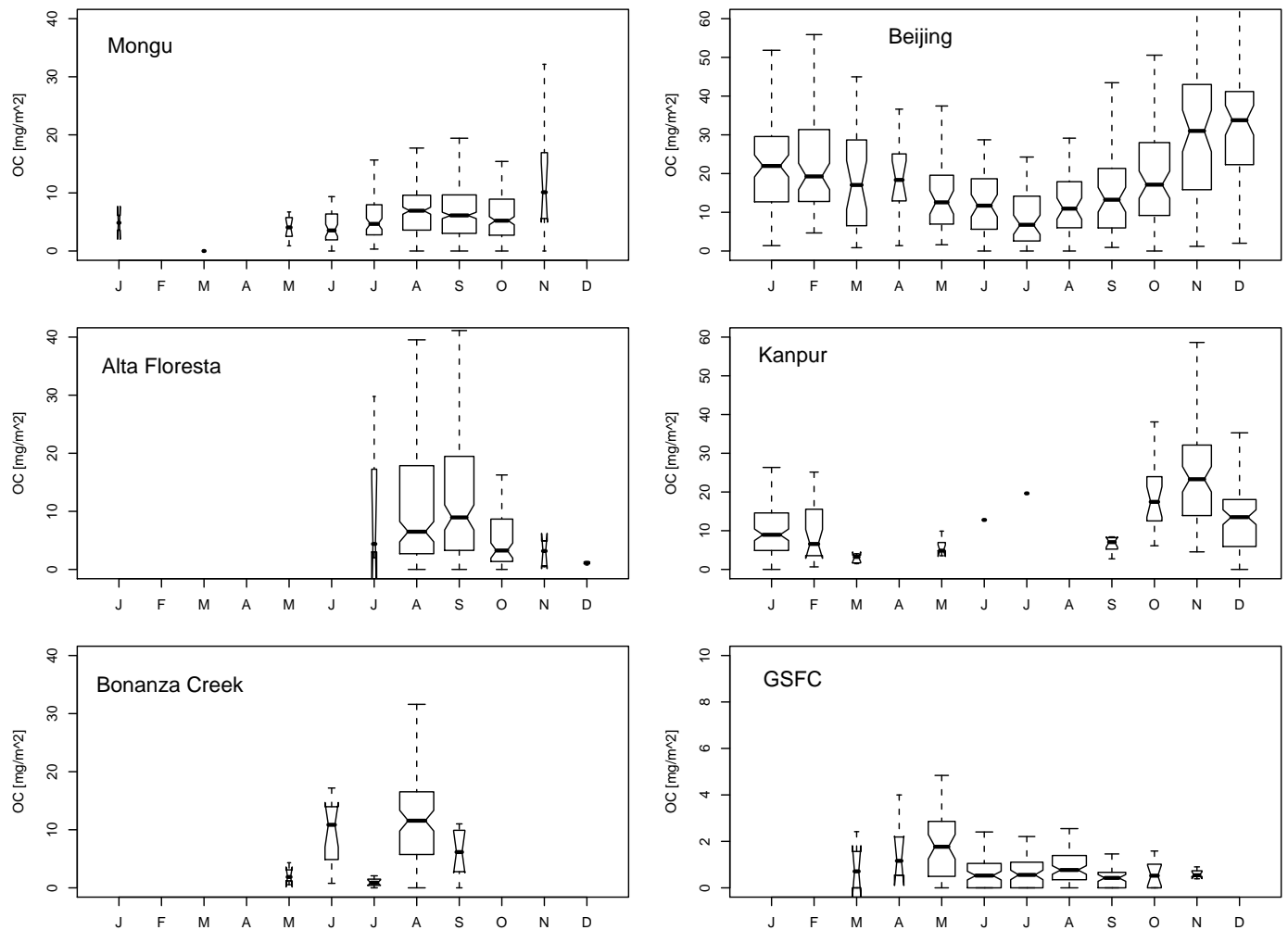

Fig. 3. Boxplot of monthly absorbing OC $\left[\mathrm{mg} \mathrm{m}^{-2}\right]$ for the following sites: Mongu, Beijing, Alta Floresta, Kanpur, Bonanza Creek, and GSFC. Non-overlapping notches indicate that those medians are statistically different. The boxes are drawn with widths proportional to the square-roots of the number of observations in each month.

We studied the seasonal patterns in absorbing organic carbon of selected AERONET-sites with very different aerosol environments. Table 2 gives the information about the locations of these sites and the data volume that was available for each month. Figure 3 shows the seasonal variation of monthly median absorbing OC at these sites. The left hand side panel includes sites with dominant biomass burning emissions, while the right hand side has mainly urban 

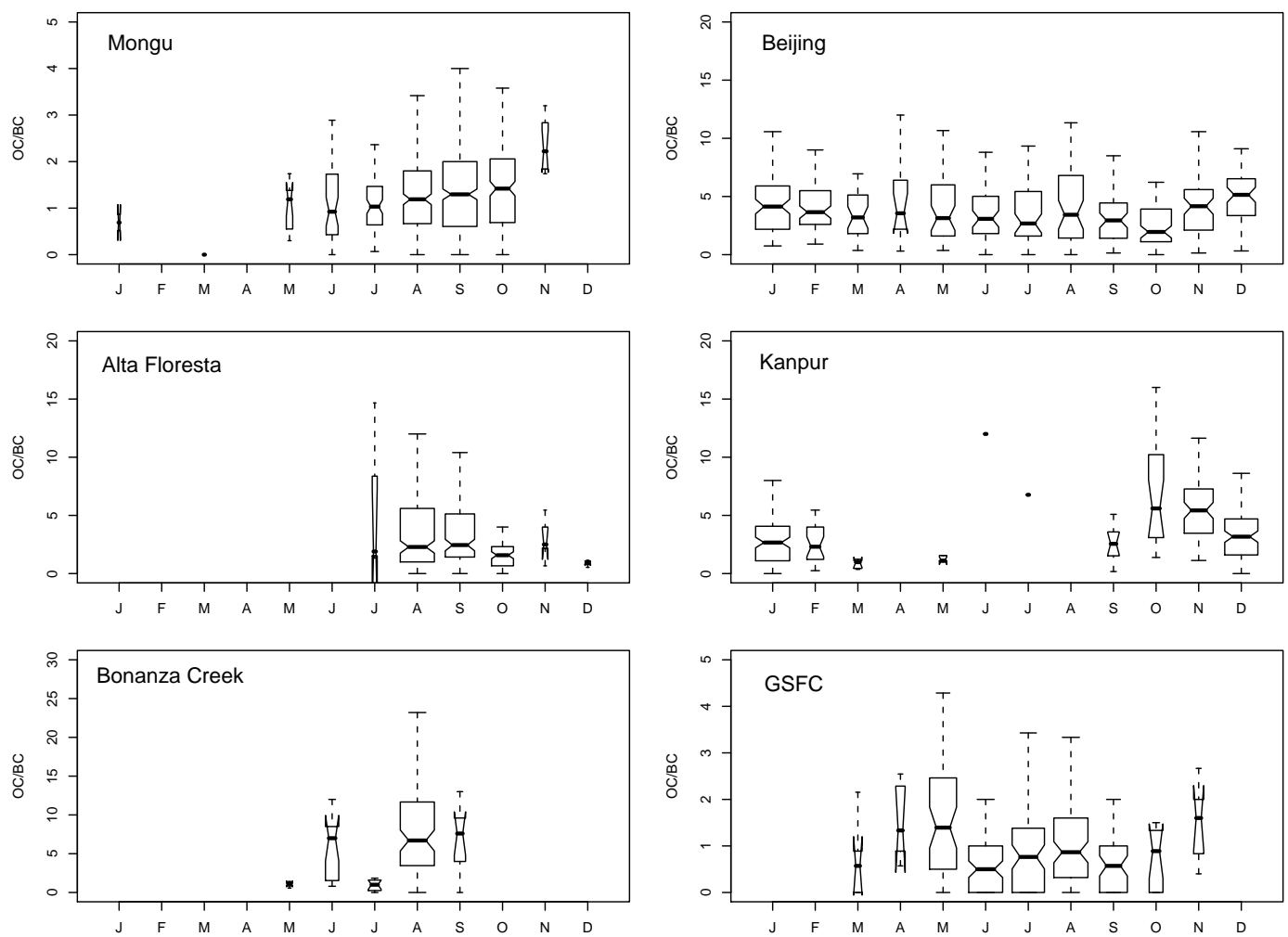

Fig. 4. Boxplot of monthly absorbing OC/BC ratio for the following sites: Mongu, Beijing, Alta Floresta, Kanpur, Bonanza Creek, and GSFC.

sites with varying emission sources. Figure 4 shows seasonal $\mathrm{OC} / \mathrm{BC}$ for the same sites. The data are represented as boxplots with notches, in order to give not only the median but also an impression about the variability in each month. Non-overlapping notches indicate that those medians are statistically different. Moreover, the boxes are drawn with widths proportional to the square-roots of the number of observations in each month. Highest monthly median value of $\mathrm{OC} / \mathrm{BC}$ is in Bonanza Creek. These $\mathrm{OC}$ and $\mathrm{BC}$ emissions are mostly from boreal forest fires, $\mathrm{OC} / \mathrm{BC}$ ratios from boreal forest fires are higher than from extratropical vegetation fires (e.g Andreae and Merlet, 2001). The imaginary refractive index of the Alaska smoke observations, analyzed by Eck et al. (2009), showed low values implying small BC fraction, and a very large relative increase towards lower wavelengths, likely resulting from enhanced absorption by OC, which is evident also in our retrievals. From the biomass burning sites, Alta Floresta exhibits somewhat larger $\mathrm{OC} / \mathrm{BC}$ ratio than Mongu. Alta Floresta is mainly surrounded by tropical forest and to less extent by savanna (Cerrado), while Mongu is mainly surrounded by savanna, evident for instance by the proportions of vegetation types presented in Ichoku et al. (2008). Cuiaba Miranda (retrievals not shown) is in the transition zone to Cerrado with less primary forest around than in Alta Floresta, however it exhibits rather similar absorbing OC concentrations. Value for $\mathrm{OC} / \mathrm{BC}$ based on emission estimates of OC and BC by Savanna type, given in Andreae and Merlet (2001), is about 7.1, while it is 8.0 for Tropical Forest. Given the uncertainties involved in these estimates, the difference is very small, however it is in the same direction than our retrievals of OC/BC for Mongu and Alta Floresta. Reid et al. (2005) also reviewed observations on biomass burning emissions and gave ranges for BC/OC (in their Table 2) for different vegetation types. OC/BC for Savanna type (e.g. Mongu) ranges from 4.3-16. The values for boreal forest (e.g. Bonanza Creek) range from 12.5-33. Therefore, against these estimates too, our retrievals are consistent with the in-situ measurements conducted in these environments.

Retrievals in Kanpur (and Gandhi College located also in Indo-Gangetic Plain, retrievals not shown) give relatively high absorbing OC concentrations for October-December period, when very high biomass burning (BB) occurs in this season (Tripathi et al., 2005a; Ganguly et al., 2009). Surface measurements of OC (Ram et al., 2010) in Kanpur, taking a boundary layer thickness of about $1 \mathrm{~km}$ (Tripathi et al., $2005 \mathrm{~b}$ ) and assuming that most OC reside within boundary layer, give a columnar OC of $38 \mathrm{mg} \mathrm{m}^{-2}$ for OctoberDecember which is somewhat higher than predicted by the present retrieval, moreover their data show highest $\mathrm{OC}$ in December, while our retrieval gives highest absorbing OC amount for November. 
Table 3. Comparison of monthly mean OC $\left(\mathrm{mg} \mathrm{m}^{-2}\right)$ from Oslo CTM and those retrieved from AERONET imaginary index. First are the AERONET-based OC concentrations (fine mode only in parenthesis), the model-based OC concentrations after the slash.

\begin{tabular}{lrrrr}
\hline Month & Beijing & Kanpur & Mongu & Alta Floresta \\
\hline 1 & $38.29(21.92) / 5.84$ & $16.29(9.95) / 7.45$ & $-(-) /-99.00$ & $-(-)$ \\
2 & $33.20(19.58) / 9.20$ & $16.84(10.27) / 8.45$ & $-(-) /-99.00$ & $-(-)$ \\
3 & $28.28(16.54) / 3.85$ & $-(-) / 10.35$ & $-(-) /-99.00$ & $-(-)$ \\
4 & $27.81(16.25) / 7.55$ & $-(-) / 6.69$ & $-(-) /-99.00$ & $-(-)$ \\
5 & $20.86(11.79) / 6.49$ & $-(-) / 5.54$ & $5.97(4.08) /-99.00$ & $-(-)$ \\
6 & $20.22(11.94) / 9.35$ & $-(-) / 6.99$ & $6.50(4.70) / 19.18$ & $-(-)$ \\
7 & $12.74(8.49) / 11.85$ & $-(-) / 8.57$ & $9.56(6.39) / 22.30$ & $-(-)$ \\
8 & $19.83(11.78) / 11.88$ & $-(-) / 9.62$ & $16.70(11.37) / 28.04$ & $17.65(13.82)$ \\
9 & $22.62(13.04) / 9.90$ & $11.04(7.17) / 15.13$ & $12.94(8.57) / 26.74$ & $19.86(15.55)$ \\
10 & $29.20(16.43) / 8.72$ & $32.71(17.81) / 14.60$ & $9.40(6.12) / 19.21$ & $7.94(5.73)$ \\
11 & $41.91(23.56) / 7.86$ & $36.74(20.43) / 10.08$ & $19.46(12.57) / 14.74$ & $-(-)$ \\
12 & $51.10(28.85) / 7.31$ & $20.75(11.94) / 10.97$ & $-(-) /-99.00$ & $-(-)$ \\
\hline
\end{tabular}

The retrieved OC concentrations in some areas that are affected strongly also by urban pollution (e.g. Beijing, Kanpur) are higher than those influenced mainly by biomass burning (e.g. Zambia, Brazil) This may seem first unexpected, however not much is currently known about brown carbon emissions from residential biofuels (Venkataraman et al., 2005) or from coal-burning aerosols, for instance, abundantly emitted particularly in these urban areas. Coal in China and other developing countries is widely used and furthermore, in many cases purposefully burnt inefficiently, to prolong the burning time (Yang et al., 2009), thus a further increase in brown carbon amount is a likely consequence. Cao et al. (2007) reports seasonal surface OC measurements in Beijing that are consistent with Lin et al. (2009), we also observe similarly strong seasonality with largest values in winter. Lin et al. (2009) explained their high winter-time OC concentrations by significant coal burning during the heating period, particularly in rather close proximity to Beijing AERONET site. Although we tried to exclude the absorption by minerals, it has to be recognized that dust contamination is still possible in our retrievals to some extent. For example, Han et al. (2007) showed some rather high concentrations of mineral aerosols in the fine mode during the winter and spring in Beijing, and smaller amounts in the summer and fall.

Table 3 includes the comparison of monthly mean OC against modeling result from Oslo CTM-2 model (Myhre et al., 2009; Myhre, 2009). The model-based monthly mean OC data were taken from the cases when AOD at $440 \mathrm{~nm}$ was larger than 0.4 , to be consistent with this same requirement in the AERONET Level-2 data. In the OC retrievals we have used total volume concentration (Eq. 2), in other words equal fractions of organic carbon in the fine and coarse modes. Schuster et al. (2005) made this same assumption and moreover justified this being consistent with AERONET inversion where all particles have the same refractive index (Dubovik and King, 2000). However, in the Table 3 we also include the OC retrievals assuming volume concentration of fine mode only (the value in parenthesis).

The model peak months seem to take place earlier in many of the sites compared to AERONET-based values, which is more evident in Beijing and Kanpur than in BB sites. For instance, in Kanpur the model-based peak values occur in September-October, while highest AERONET-based absorbing OC concentrations are in October-November. The model gives higher OC concentrations in both biomass burning sites if compared to our AERONET-based retrievals. One has to keep in mind that model values take into account all the organic compounds, while our approach effectively gives "absorbing OC"; by definition components causing enhanced absorption at the shortest wavelengths. Measurement-based BC data, applicable to model comparison are sparse, which makes the effort by Koch et al. (2009) a very valuable study, also to evaluate the black carbon emissions applied by the models. The column data for OC are even more sparse, so the main motivation for our study was to establish such a data set from the AERONET measurements. Although there are significant uncertainties involved in our approach, mainly due to the fact that there exist numerous organic species with varying absorption characteristics (i.e. imaginary indices that are not well known), we want to emphasize that all the AERONET retrievals were consistently processed. Therefore, arguably the relative patterns, i.e. differences between regions and temporal variability in any given site, likely reveal more about the quality of the model emissions than absolute levels. Even if assuming fine mode concentration only in our retrieval, the model-based OC concentrations in Beijing and Kanpur are lower than our retrievals. Underestimation in absorption optical depth was found in Sato et al. (2003) for these sites by both models that they include. They did not consider separately the influence by OC, while they increased both $\mathrm{BC}$ and $\mathrm{OC}$ to retrieve the best match between two global models and AERONET data. 
There are not many measured refractive indices for OC species available at the wavelengths we are restricted to use now with the AERONET measurements. For instance, Kanakidou et al. (2005) (in their Fig. 7) give optical constants of several organic components, most of which taken from Jacobson (1999), but all these imaginary indices are around $350 \mathrm{~nm}$ or lower. However, in order to carry out a sensitivity of our retrieval approach, we estimated absorbing OC concentrations using imaginary index values reported by Sun et al. (2007) and Chen and Bond (2010). Chen and Bond (2010) values are smaller than those of Kirchstetter et al. (2004) used in our study, therefore our retrieved absorbing OC concentrations in turn are lower. By using the refractive indices from Sun et al. (2007) and Chen and Bond (2010) we estimated the sensitivity of our approach to the assumed imaginary index values. We inferred the imaginary index from $\frac{\alpha}{\rho}$ (absorption per mass column concentration in $\mathrm{cm}^{2} \mathrm{~g}^{-1}$ ) values provided by Chen and Bond (2010) and Sun et al. (2007), assuming the same density we used in our retrieval $\left(1.2 \mathrm{~g} \mathrm{~cm}^{-3}\right)$. Table 1 shows the imaginary index values at $440 \mathrm{~nm}$ and $670 \mathrm{~nm}$ from Sun et al. (2007) and Chen and Bond (2010) that we used in our sensitivity study. Figure 5 shows the monthly mean absorbing OC concentrations for Mongu with the two different imaginary index spectra from Chen and Bond (2010), for $210^{\circ} \mathrm{C}$ and $360^{\circ} \mathrm{C}$ production temperatures and two values from Sun et al. (2007), for water soluble organic carbon (WSOC) and water-insoluble organic carbon (WISOC). The relative changes in absorbing OC, due to these same different refractive index values, are similar in any other site. It is clear that the retrieved absorbing OC concentrations are sensitive to the assumed imaginary index. If lower values of imaginary index for $440 \mathrm{~nm}$ and $670 \mathrm{~nm}$ are used in our retrieval instead of Kirchstetter et al. (2004), significantly higher absorbing OC concentrations are retrieved for these biomass burning sites. In an ideal situations, there were regionally varying and ecotype dependent imaginary index values in our retrieval. Unfortunately, currently there are not sufficient data for this purpose. However, with the sensitivity study we wanted to highlight the importance of the imaginary index data in this kind of approach.

Figure 6 shows the normalized frequency of mass absorption efficiency (MAE) of organic carbon at $440 \mathrm{~nm}$, assuming the same imaginary index values for $\mathrm{OC}$ and shown in same colors as in the previous figure. The curves in each figure are normalized with the data amount of that site and can be therefore compared in interpreting how the MAE data are distributed. Moreover, y-axis is shown only up to 10 , in order to focus more clearly on the range where most MAE values exist. Same six sites are included than in the Figs. 3 and 4.

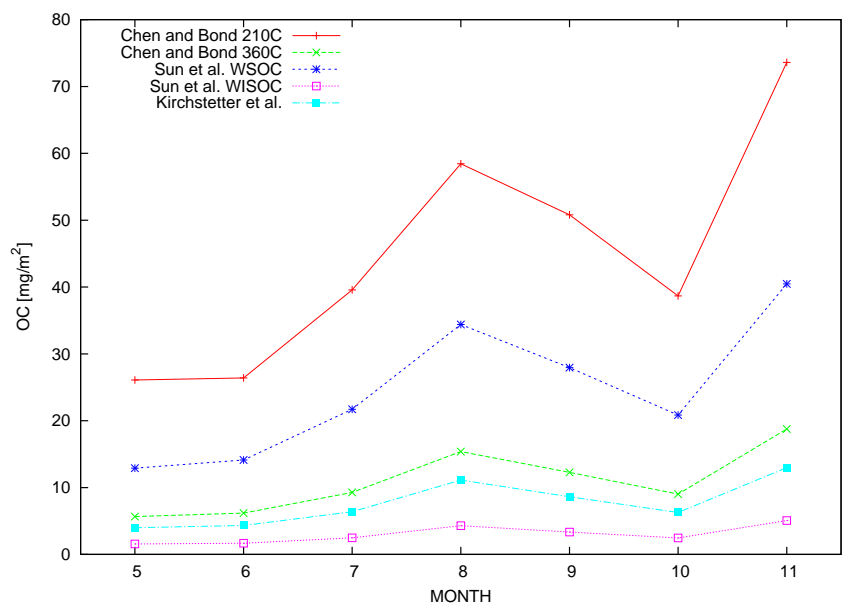

Fig. 5. Monthly mean absorbing OC $\left[\mathrm{mg} \mathrm{m}^{-2}\right]$ for Mongu, assuming different imaginary index values for OC. Kirchstetter et al. (2004) based values correspond to the retrievals presented in this paper. Sensitivity study was carried out applying also imaginary index values presented in Chen and Bond (2010) for two production temperatures and in Sun et al. (2007) for water soluble (WSOC) and water-insoluble organic carbon (WISOC).

The absorption by black carbon at $440 \mathrm{~nm}, \tau_{\mathrm{abs} B C}$, was estimated by extrapolating from absorption optical depth at $670 \mathrm{~nm}$ using an AAE of 1 . Then the difference between the AERONET-measured absorption optical depth, $\tau_{\mathrm{abs}}$, and the estimated absorption optical depth by black carbon at $440 \mathrm{~nm}$ was assumed to be due to the organic carbon. MAE is then absorption optical depth by organic carbon divided by the retrieved absorbing organic carbon.

$\mathrm{MAE}=\frac{\tau_{\mathrm{abs}}-\tau_{\mathrm{abs} B C}}{[\mathrm{OC}]}$,

These histograms provide another approach to assess the uncertainty in our retrieval. Intrinsic parameters like MAE are sensitive to aerosol size and composition (but not to the aerosol mass) and remain relatively constant with respect to altitude in well-mixed aerosol layers. Since intrinsic parameters are not sensitive to the physical thickness of the aerosol layer, MAE is a better parameter for comparison to surface measurements than column aerosol volume (or mass) in regions dominated by a single aerosol layer.

As an additional uncertainty in our MAE estimate, it must be noted that the absorption Angstrom exponent can deviate from one (i.e., $\mathrm{AAE} \neq 1$ ) for black carbon particles that are sufficiently large or internally mixed with other aerosols (Bohren and Huffman, 1983; Bond, 2001; Lack and Cappa, 2010).

Some estimates of MAE of OC have been published. Barnard et al. (2008) summarize in their Fig. 5 their estimates with those from Sun et al. (2007) and Kirchstetter et al. (2004), giving MAE range at $440 \mathrm{~nm}$ from 1 to 3 . Most of our 

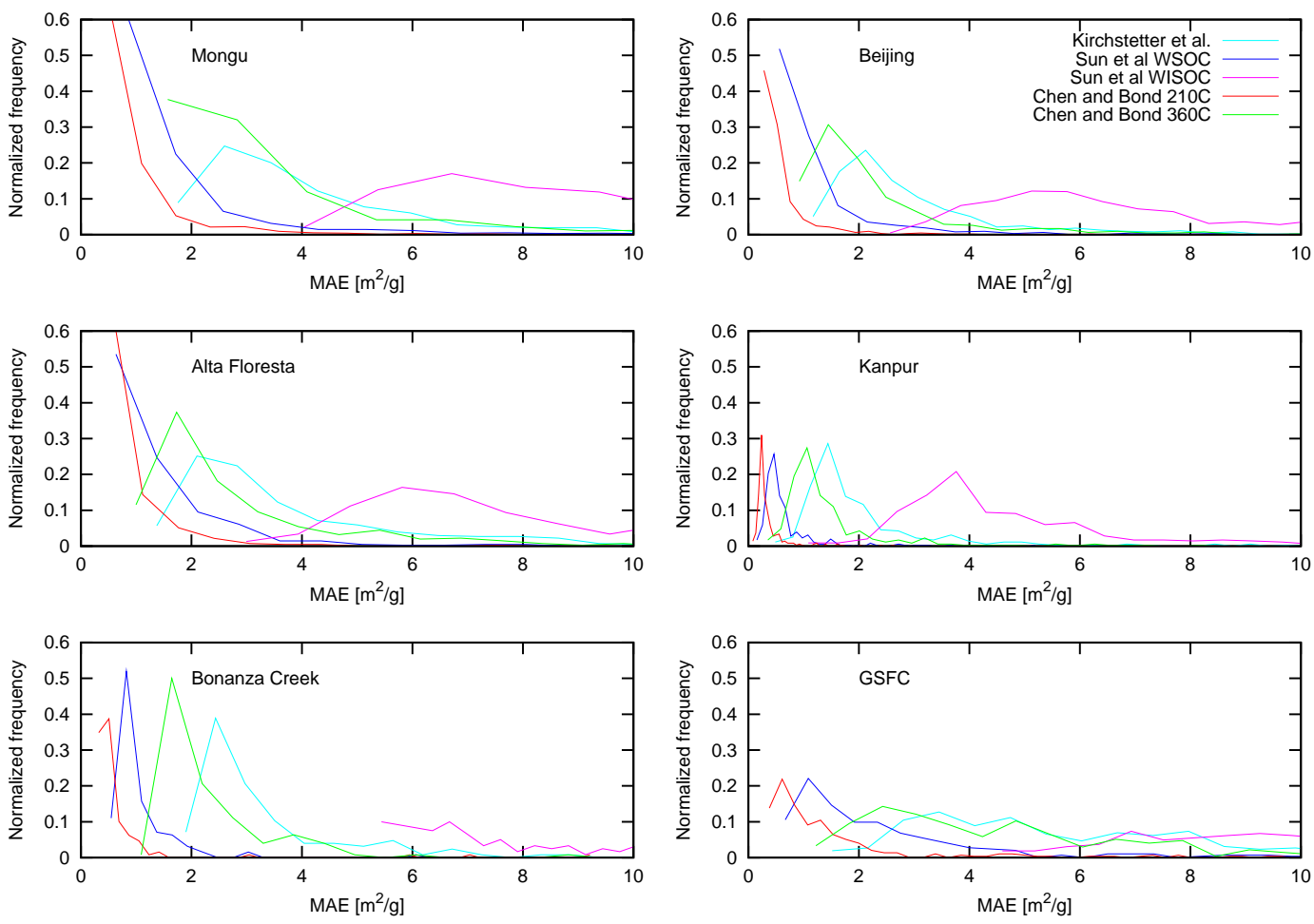

Fig. 6. Normalized frequency of mass absorption efficiency (MAE) of organic carbon in $\mathrm{m}^{2} \mathrm{~g}^{-1}$, assuming the same imaginary index values for OC than in the Fig. 5. Following sites are included: Mongu, Beijing, Alta Floresta, Kanpur, Bonanza Creek, and GSFC.

MAE values lie in that range when assuming imaginary index for OC from Kirchstetter et al. (2004) or Chen and Bond (2010) at $360^{\circ} \mathrm{C}$.

\section{Conclusions}

We have used AERONET aerosol spectral refractive indices following an improved methodology of Schuster et al. (2005) to obtain columnar absorbing organic carbon $(\mathrm{OC})$ and black carbon contents. One of the main assumptions in this approach is that higher imaginary index values at two shortest wavelengths $(440 \mathrm{~nm}$ and $670 \mathrm{~nm})$ are attributed to the absorption by organics (brown carbon), when we attempt to exclude the dust absorption. In terms of AAE, this means that AAE values higher than one (which is the estimated value for $\mathrm{BC}$ absorption) are due to the light-absorbing organic carbon. The actual retrieved absorbing organic carbon concentration then depends substantially on the assumed imaginary index for $440 \mathrm{~nm}$ and $670 \mathrm{~nm}$, as was shown in the Fig. 5 . However, given the current uncertainties in our knowledge of formation and absorption properties of organic carbon and lack of global data of absorbing organic carbon, a new approach to estimate both regional (e.g. differences between urban and biomass burning dominated sites) and temporal variability in light-absorbing organics are needed. Our study is a step towards this direction and offers the first AERONET- based estimates of absorbing organic carbon concentrations. Future work is needed on the refractive indexes of several absorbing OC species, to improve the understanding of abundance of absorbing OC.

Our main findings are:

1. We attribute the enhanced absorption at the shortest retrieval wavelength $(440 \mathrm{~nm})$ of several AERONET sites to organic carbon. Although we restrict our analysis to fine mode volume concentrations greater than 0.5 , some of this enhanced absorption could still be associated with dust contamination. In any case, this enhanced absorption is very relevant for the radiative forcing of the direct aerosol effect.

2. There are significant uncertainties in our OC retrievals, mainly due to the imaginary index assumed for OC. There are other sources of uncertainty as well, such as the assumption of OC density.

3. Absorbing OC retrievals from Beijing and XiangHe clearly dominates in winter season (up to $35 \mathrm{mg} \mathrm{m}^{-2}$ ), and they show highest values also in other seasons except for September-November, when retrievals from Kanpur and Gandhi College exhibit highest values due to very high biomass burning occurring in this season. The highest OC concentrations in these areas of China and India are affected likely also by urban pollution, 
industrial sources, and domestic heating. In the summer the values of absorbing OC concentration are very similar in US and Europe (around $5 \mathrm{mg} \mathrm{m}^{-2}$ ), while in the Southern Hemisphere they are typically around 15$20 \mathrm{mg} \mathrm{m}^{-2}$.

4. In any season, the grid-box including Beijing and $\mathrm{Xi}$ angHe exhibits the highest $\mathrm{OC} / \mathrm{BC}$ ratio, and the one including Kanpur and Gandhi College has also high $\mathrm{OC} / \mathrm{BC}$ ratio. In the summer season the $\mathrm{OC} / \mathrm{BC}$ ratios in Alaska and around Moscow were rather high. These OC and $\mathrm{BC}$ emissions are mostly from boreal forest fires.

Acknowledgements. S. N. Tripathi acknowledges support from Department of Science and Technology, ICRP and Indian Space Research Organisation GBP programmes. S. N. Tripathi was also supported in part by appointment to the NASA Postdoctoral Program at Goddard Space Flight Center, administered by Oak Ridge Associated Universities through a contract with NASA. SK would like to acknowledge Marie Curie project ACI-UV PERG05-GA-2009-247492.

Edited by: J. Quaas

\section{References}

Alexander, D. T. L., Crozier, P. A., and Anderson, J. R.: Brown carbon spheres in East Asian outflow and their optical properties, Science, 321, 833-836, 2008.

Andreae, M. O. and Gelencsér, A.: Black carbon or brown carbon?, The nature of light-absorbing carbonaceous aerosols, Atmos. Chem. Phys., 6, 3131-3148, doi:10.5194/acp-6-3131-2006, 2006.

Andreae, M. O. and Merlet, P.: Emission of Trace Gases and Aerosols From Biomass Burning, Global Biogeochem. Cy., 15(4), 955-966, 2001.

Barnard, J. C., Volkamer, R., and Kassianov, E. I.: Estimation of the mass absorption cross section of the organic carbon component of aerosols in the Mexico City Metropolitan Area, Atmos. Chem. Phys., 8, 6665-6679, doi:10.5194/acp-8-6665-2008, 2008.

Bergstrom, R. W., Pilewskie, P., Russell, P. B., Redemann, J., Bond, T. C., Quinn, P. K., and Sierau, B.: Spectral absorption properties of atmospheric aerosols, Atmos. Chem. Phys., 7, 5937-5943, doi:10.5194/acp-7-5937-2007, 2007.

Bohren, C. F and Huffman, D. R.: Absorption and Scattering of Light by Small Particles, New York: Wiley, 1983.

Bond, T. C.: Spectral dependence of visible light absorption by carbonaceous particles emitted from coal combustion, Geophys. Res. Lett., 28(21), 4075-4078, doi:10.1029/2001GL013652, 2001.

Bond, T. and Bergstrom, R.: Light absorption by carbonaceous particles: An investigative review, Aerosol Sci. Technol., 40(1), 2767, 2006.

Cao, J. J., Lee, S. C., Chow, J. C., Watson, J. G., Ho, K. F., Zhang, R. J., Jin, Z. D., Shen, Z. X., Chen, G. C., Kang, Y. M., Zou, S. C., Zhang, L. Z., Qi, S. H., Dai, M. H., Cheng, Y., and $\mathrm{Hu}, \mathrm{K}$.: Spatial and seasonal distributions of carbonaceous aerosols over China, J. Geophys. Res., 112, D22S11, doi:10.1029/2006JD008205, 2007.
Chen, Y. and Bond, T. C.: Light absorption by organic carbon from wood combustion, Atmos. Chem. Phys., 10, 1773-1787, doi:10.5194/acp-10-1773-2010, 2010.

Dey, S., Tripathi, S. N., Singh, R. P., and Holben, B.: Retrieval of black carbon and specific absorption over Kanpur city, Northern India during 2001-2003 using AERONET data, Atmos. Environ., 40(3), 445-456, 2006.

Dubovik, O. and King, M. D.: A flexible inversion algorithm for retrieval of aerosol optical properties from Sun and sky radiance measurements, J. Geophys. Res., 105(D16), 20673-20696, 2000.

Eck, T. F., Holben, B. N., Reid, J. S., Sinyuk, A., Hyer, E. J., O’Neill, N. T., Shaw, G. E., Vande Castle, J. R., Chapin, F. S., Dubovik, O., Smirnov, A., Vermote, E., Schafer, J. S., Giles, D., Slutsker, I., Sorokine, M., and Newcomb, W. W.: Optical properties of boreal region biomass burning aerosols in central Alaska and seasonal variation of aerosol optical depth at an Arctic coastal site, J. Geophys. Res., 114, D11201, doi:10.1029/2008JD010870, 2009.

Ganguly, D., P. Ginoux, V., Ramaswamy, D. M., Winker, B. N., Holben, and Tripathi, S. N.: Retrieving the composition and concentration of aerosols over the Indo-Gangetic basin using CALIOP and AERONET data, Geophys. Res. Lett., 36, L13806, doi:10.1029/2009GL038315, 2009.

Han, L., Zhuang G., Cheng, S., Li, J., The mineral aerosol and its impact on urban pollution aerosols over Beijing, China, Atmos. Environ., 41(35), 7533-7546, doi:10.1016/j.atmosenv.2007.05.046, 2007.

Holben, B. N., Eck, T. F., Slutsker, I., Tanre, D., Buis, J. P., Setzer, A., Vermote, E., Reagan, J. A., Kaufman, Y., Nakajima, T., Lavenu, F., Jankowiak, I., and Smirnov, A.: AERONET - A federated instrument network and data archive for aerosol characterization, Remote Sens. Environ., 66, 1-16, 1998.

Ichoku, C., Giglio, L., Wooster, M. J., and Remer, L. A.: Global characterization of biomass-burning patterns using satellite measurements of Radiative Energy, Remote Sens. Environ., 112, 2950-2962, 2008..

Intergovernmental Panel on Climate Change (IPCC), Climate Change 2007: The Scientific Basis. Contribution of Working Group I to the Fourth Assessment Report of the Intergovernmental Panel on Climate Change, edited by: Solomon, S., Qin, D., Manning, M., Chen, Z., Marquis, M., Averyt, K. B., Tignor M., and Miller, H. L., Cambridge Univ. Press, New York, 2007.

Jacobson, M. Z.: Isolating nitrated and aromatic aerosols and nitrated aromatic gases as sources of ultraviolet light absorption, J. Geophys. Res., 104(D3), 3527-3542, doi:10.1029/1998JD100054, 1999.

Kanakidou, M., Seinfeld, J. H., Pandis, S. N., Barnes, I., Dentener, F. J., Facchini, M. C., Van Dingenen, R., Ervens, B., Nenes, A., Nielsen, C. J., Swietlicki, E., Putaud, J. P., Balkanski, Y., Fuzzi, S., Horth, J., Moortgat, G. K., Winterhalter, R., Myhre, C. E. L., Tsigaridis, K., Vignati, E., Stephanou, E. G., and Wilson, J.: Organic aerosol and global climate modelling: a review, Atmos. Chem. Phys., 5, 1053-1123, doi:10.5194/acp-5-1053-2005, 2005.

Kirchstetter, T. W., Novakov, T., and Hobbs, P. V.: Evidence that the spectral dependence of light absorption by aerosols is affected by organic carbon, J. Geophys. Res., 109, D21208, doi:10.1029/2004JD004999, 2004.

Koch, D., Schulz, M., Kinne, S., McNaughton, C., Spackman, J. 
R., Balkanski, Y., Bauer, S., Berntsen, T., Bond, T. C., Boucher, O., Chin, M., Clarke, A., De Luca, N., Dentener, F., Diehl, T., Dubovik, O., Easter, R., Fahey, D. W., Feichter, J., Fillmore, D., Freitag, S., Ghan, S., Ginoux, P., Gong, S., Horowitz, L., Iversen, T., Kirkevåg, A., Klimont, Z., Kondo, Y., Krol, M., Liu, X., Miller, R., Montanaro, V., Moteki, N., Myhre, G., Penner, J. E., Perlwitz, J., Pitari, G., Reddy, S., Sahu, L., Sakamoto, H., Schuster, G., Schwarz, J. P., Seland, Ø., Stier, P., Takegawa, N., Takemura, T., Textor, C., van Aardenne, J. A., and Zhao, Y.: Evaluation of black carbon estimations in global aerosol models, Atmos. Chem. Phys., 9, 9001-9026, doi:10.5194/acp-9-9001-2009, 2009.

Koven, C. D. and Fung, I.: Inferring dust composition from wavelength-dependent absorption in Aerosol Robotic Network (AERONET) data, J. Geophys. Res., 111, D14205, doi:10.1029/2005JD006678, 2006.

Lack, D. A. and Cappa, C. D.: Impact of brown and clear carbon on light absorption enhancement, single scatter albedo and absorption wavelength dependence of black carbon, Atmos. Chem. Phys., 10, 4207-4220, doi:10.5194/acp-10-4207-2010, 2010.

Laskin, J., Laskin, A., Roach, P. J., Slysz, G. W., Anderson, G. A., Nizkorodov, S., Bones, D. L., and Nguyen, L.: High-Resolution desorption electrospray ionization mass spectrometry for chemical characterization of organic aerosols, Anal. Chem., 82(5), 2048-2058, doi:10.1021/ac902801f, 2010.

Lewis, K., Arnott, W. P., Moosmüller, H., and Wold, C. E.: Strong spectral variation of biomass smoke light absorption and single scattering albedo observed with a novel dual-wavelength photoacoustic instrument, J. Geophys. Res., 113, D16203, doi:10.1029/2007JD009699, 2008.

Lin, P., Hu, M., Deng, Z., Slanina, J., Han, S., Kondo, Y., Takegawa, N., Miyazaki, Y., Zhao, Y., and Sugimoto, N.: Seasonal and diurnal variations of organic carbon in PM2.5 in Beijing and the estimation of secondary organic carbon, J. Geophys. Res., 114, D00G11, doi:10.1029/2008JD010902, 2009.

Luhar, A. K., Mitchell, R. M., Meyer, C. P. M., Qin, Y., Campbell, S. K., Gras, J. L., and Parry, D.: Biomass burning emissions over northern Australia constrained by aerosol measurements: II model validation, and impacts on air quality and radiative forcing, Atmos. Environ., 42, 1647-1664, 2008.

Martins, J. V., Artaxo, P., Kaufman, Y. J., Castanho, A. D., and Remer, L. A.: Spectral absorption properties of aerosol particles from 350-2500 nm, Geophys. Res. Lett., 36, L13810, doi:10.1029/2009GL037435, 2009.

Myhre, G., Berglen, T. F., Johnsrud, M., Hoyle, C. R., Berntsen, T. K., Christopher, S. A., Fahey, D. W., Isaksen, I. S. A., Jones, T. A., Kahn, R. A., Loeb, N., Quinn, P., Remer, L., Schwarz, J. P., and Yttri, K. E.: Modelled radiative forcing of the direct aerosol effect with multi-observation evaluation, Atmos. Chem. Phys., 9, 1365-1392, doi:10.5194/acp-9-1365-2009, 2009.

Myhre, G.: Consistency between satellite-derived and modeled estimates of the direct aerosol effect, Science, 325, 187-190, doi:10.1126/science.1174461, 2009.

Qin, Y. and Mitchell, R. M.: Characterisation of episodic aerosol types over the Australian continent, Atmos. Chem. Phys., 9, 1943-1956, doi:10.5194/acp-9-1943-2009, 2009.

Ram, K., Sarin, M. M., and Tripathi, S. N.: A 1 year record of carbonaceous aerosols from an urban site in the Indo-Gangetic Plain: Characterization, sources, and temporal variability, J.
Geophys. Res., 115, D24313, doi:10.1029/2010JD014188, 2010.

Reid, J. S., Koppmann, R., Eck, T. F., and Eleuterio, D. P.: A review of biomass burning emissions part II: intensive physical properties of biomass burning particles, Atmos. Chem. Phys., 5, 799825, doi:10.5194/acp-5-799-2005, 2005.

Russell, P. B., Bergstrom, R. W., Shinozuka, Y., Clarke, A. D., DeCarlo, P. F., Jimenez, J. L., Livingston, J. M., Redemann, J., Dubovik, O., and Strawa, A.: Absorption Angstrom Exponent in AERONET and related data as an indicator of aerosol composition, Atmos. Chem. Phys., 10, 1155-1169, doi:10.5194/acp10-1155-2010, 2010.

Sato, M., Hansen, J., Koch, D., Lacis, A., Ruedy, R., Dubovik, O., Holben, B., Chin, M., and Novakov, T.: Global atmospheric black carbon inferred from AERONET, P. Natl. Acad. Sci., 100, 6319-6324, 2003.

Schuster, G. L., Dubovik, O., Holben, B. N., and Clothiaux, E. E.: Inferring black carbon content and specific absorption from Aerosol Robotic Network (AERONET) aerosol retrievals, J. Geophys. Res., 110, D10S17, doi:10.1029/2004JD004548, 2005.

Schuster, G. L., Lin, B., and Dubovik, O.: Remote sensing of aerosol water uptake, Geophys. Res. Lett., 36, L03814, doi:10.1029/2008GL036576, 2009.

Shinozuka, Y., Clarke, A. D., DeCarlo, P. F., Jimenez, J. L., Dunlea, E. J., Roberts, G. C., Tomlinson, J. M., Collins, D. R., Howell, S. G., Kapustin, V. N., McNaughton, C. S., and Zhou, J.: Aerosol optical properties relevant to regional remote sensing of $\mathrm{CCN}$ activity and links to their organic mass fraction: airborne observations over Central Mexico and the US West Coast during MILAGRO/INTEX-B, Atmos. Chem. Phys., 9, 6727-6742, doi:10.5194/acp-9-6727-2009, 2009.

Sun, H., Biedermann, L., and Bond, T. C.: Color of brown carbon: A model for ultraviolet and visible light absorption by organic carbon aerosol, Geophys. Res. Lett., 34, L17813, doi:10.1029/2007GL029797, 2007.

Tripathi, S. N., S. Dey, V. Tare, and S. K. Satheesh: Aerosol black carbon radiative forcing at an industrial city in northern India, Geophysical Research Letters, 32, L08802, doi:10.1029/2005GL022515, 2005a.

Tripathi, S. N., S. Dey, V. Tare, S. K. Satheesh, S. Lal and S. Venkataramni:, Enhanced layer of black carbon in a north Indian industrial city, Geophys. Res. Lett., 32(12), L12802, doi:10.1029/2005GL022564, 2005b.

Turpin. B. J. and Lim, H. J.: Species contributions to $\mathrm{PM}_{2.5}$ mass concentrations: Revisiting common assumptions for estimating organic mass, Aerosol Sci Technol., 35, 602-610, 2001.

Venkataraman, C., Habib, G., Eiguren-Fernandez, A., Miguel, A. H., and Friedlander, S. K.: Residential biofuels in South Asia: Carbonaceous aerosol emissions and climate impacts, Science, 307(5714), 1424-1426, 2005.

Yang, M., Howell, S. G., Zhuang, J., and Huebert, B. J.: Attribution of aerosol light absorption to black carbon, brown carbon, and dust in China - interpretations of atmospheric measurements during EAST-AIRE, Atmos. Chem. Phys., 9, 2035-2050, doi:10.5194/acp-9-2035-2009, 2009. 